\title{
Record of insects in two fern species of the genus Microgramma (Polypodiaceae) in the Atlantic Rain Forest, Rio de Janeiro state, Brazil
}

\author{
V. C. Maia ${ }^{a}$ and M. G. Santos ${ }^{b *}$

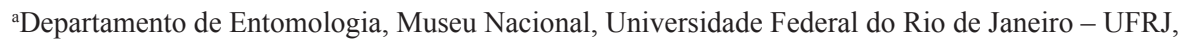 \\ Quinta da Boa Vista, CEP 20940-040, Rio de Janeiro, RJ, Brazil \\ ${ }^{\text {b}}$ Departamento de Ciências, Faculdade de Formação de Professores, Universidade do Estado do Rio de Janeiro - UERJ, \\ Dr. Francisco Portela, 1470, CEP 24435-005, São Gonçalo, RJ, Brazil \\ *e-mail: marceloguerrasantos@gmail.com
}

Received: June 9, 2014 - Accepted: August 4, 2014 - Distributed: November 30, 2015

(With 1 figure)

Insect-fern interactions are poorly documented, particularly in neotropical regions. Microgramma C.Presl is a fern genus of the Polypodiaceae family, with 18 species found in Brazil (Labiak et al., 2015). The following note reports records of insects in two Microgramma species, Microgramma vacciniifolia (Langsd. et Fisch.) Copel. and Microgramma geminata (Schrad.) R.M.Tryon et A.F.Tryon.

M. vacciniifolia is a fern epiphyte with Neotropical geographic range. It occurs in many types of vegetation and also in urban trees. In field work in the restinga (sandy coastal plains) of the Maricá Environmental Protection Area, Rio de Janeiro State, Brazil, two morphological types of galls, ellipsoid and ovoid (Figure 1a, b), were reported. Both galls were collected in a Myrtaceae "thicket" community from June 2008 to August 2009 and transported to the laboratory. Part of the sample was packed in transparent plastic bags with moist cotton and checked daily for adult emergence. The botanical dried specimens were deposited in the herbarium of the Faculdade de Formação de Professores, UERJ (RFFP) and the zoological material were incorporated into the holdings of the Museu Nacional (MNRJ), Rio de Janeiro, Brazil (Cecidomyiidae), Agência Paulista de Tecnologia dos Agronegócios (APTA), Ribeirão Preto (wasps) and Instituto Uiraçu, Bahia (micromoths).

The ellipsoid galls are induced by a micromoth (Microlepidoptera), Tortrimosaica polypodivora (Brown et Baixeras, 2004) (Figure 1a). One parasitoid wasp - Cheloninae (Braconidae) - and one inquiline species - Dasineura sp. (Cecidomyiidae) - are also found in the galls and this is the first record of both being connected to $M$. vacciniifolia. T. polypodivora also induces galls in another fern, Microgramma squamulosa (Kaulf.) de la Sota (Brown et al., 2004). Maia and Santos (2011) described Primadiplosis microgrammae (Maia, 2011) (Cecidomyiidae, Diptera) (Figure 1b) as producing the ovoid galls found in M. vacciniifolia. In the present note, we record the occurrence of two parasitoids Torymidae and Tetrastichinae (Eulophidae). Hymenoptera is also recorded in these galls for the first time.

Although these new records of wasps are presented at family or subfamily levels, they represent an important contribution due to the scarceness of data on insect-fern interactions in the neotropics. The new data indicate that these interactions are much more complex than our previous knowledge indicated.

A compilation of gall midges and host plant species of the neotropical region revealed that $92 \%$ of these species were monophagous (inducing galls on a single host plant species) and only $5.6 \%$ were oligophagous (Carneiro et al., 2009). There is currently no data available for micromoths.

The galls induced by micromoths (ellipsoid) are more frequent than those induced by midges (ovoid). The first galls can be found in M. vacciniifolia occurring in natural areas and urban trees, while the second galls are rare even in natural areas. This fern is cyanogenic. The cyanogenesis always occurs in the leaves and there is variation in the stem (Santos et al., 2005). Studies suggest that insect oviposition is stimulated by cyanoglucosides and these compounds could play an important role in host selection (Honda et al., 1997). In field work in a Clusia "scrub" community, in the Restinga de Jurubatiba National Park (Carapebus municipality, Rio de Janeiro state) another micromoth (not identified) in the pupal stage was found to use the stem of Microgramma species as camouflage. Its pupae are covered by scales of the fern species and seem a continuation of the fern stem (Figure 1c). These micromoth pupae are very rare: only two were found in field works and no adult insect emerged. They were found $M$. geminata and M. vacciniifolia ferns. The insect's mimicry in ferns has been poorly documented (Patra et al., 2008; Nervo et al., 2011). 

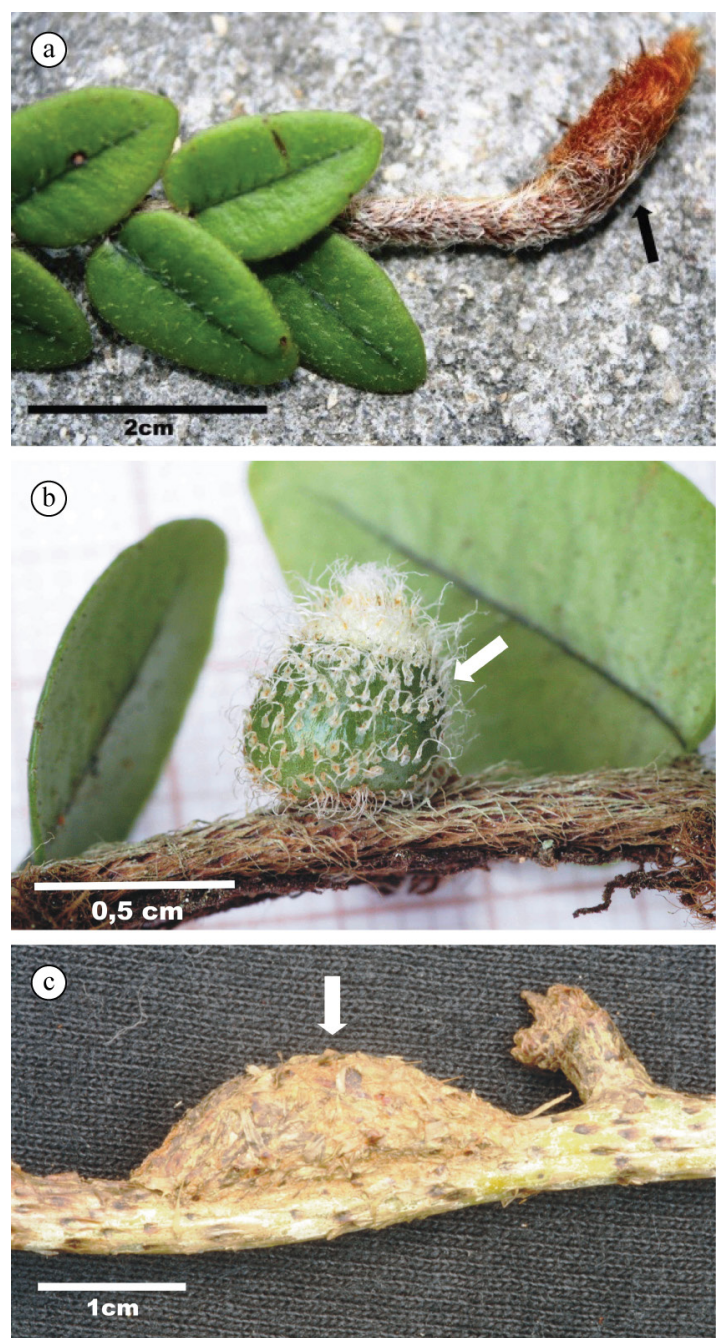

Figure 1. (a) Gall (arrow) in Microgramma vacciniifolia induced by Tortrimosaica polypodivora; (b) Gall (arrow) in Microgramma vacciniifolia induced by Primadiplosis microgrammae; (c) Micromoth pupae (arrow) camouflaged in the stem of Microgramma geminata.

\section{Acknowledgements}

The authors would like to thank CNPq (Conselho Nacional de Desenvolvimento Científico e Tecnológico, Proc. 484708/2013-9 and 311198/2013-9), FAPERJ
(Fundação Carlos Chagas Filho de Amparo à Pesquisa do Estado do Rio de Janeiro, Proc. E-26/111.490/2013) and PROCIENCIA-UERJ for financial support. Special thanks to Dr. Nelson Wanderley Perioto and Dr. Vitor O. Becker for the wasps and micromoths identification, respectively.

\section{References}

BROWN, J.W., BAIXERAS, J., SOLORZANO-FILHO, J.A. and KRAUS, J.E., 2004. Description and life history of an unusual fern-feeding tortricid moth (Lepidoptera: Tortricidae) from Brazil. Annals of the Entomological Society of America, vol. 97, no. 5, pp. 865-871. http://dx.doi.org/10.1603/0013-8746(2004)097[0865:DA LHOA]2.0.CO;2.

CARNEIRO, M.A.A., BRANCO, C.S.A., BRAGA, C.E.D., ALMADA, E.D., COSTA, M.B.M., MAIA, V.C. and FERNANDES, G.W., 2009. Are gall midge species (Diptera: Cecidomyiidae) host plant specialists? Revista Brasileira de Entomologia, vol. 53, no. 3, pp. 265-378. http://dx.doi.org/10.1590/S0085-56262009000300010.

HONDA, K., NISHII, W. and HAYASHI, N., 1997. Oviposition stimulants for sulfur ButterflyColias erate poliographys: Cyanoglucosides as synergistis involved in host preference. Journal of Chemical Ecology, vol. 23, no. 2, pp. 323-331. http:// dx.doi.org/10.1023/B:JOEC.0000006362.96722.c9.

LABIAK, P.H., HIRAI, R.Y. and ALMEIDA, T.E., 2015 [viewed 28 October 2015]. Microgramma in lista de Espécies da Flora do Brasil [online]. Jardim Botânico do Rio de Janeiro. Available from: http://floradobrasil.jbrj.gov.br/jabot/floradobrasil/FB91654.

MAIA, V.C. and SANTOS, M.G., 2011. A new genus and species of gall midge (Diptera, Cecidomyiidae) associated with Microgramma vacciniifolia (Langsd. \& Fisch.) Copel. (Polypodiaceae) from Brazil. Revista Brasileira de Entomologia, vol. 55, no. 1, pp. 40-44. http://dx.doi.org/10.1590/S0085-56262011000100008.

NERVO, M.H., WINDISCH, P.G. and SEIBERT, S., 2011. Herbivory on Pecluma pectinatiformis (L.) Price (Polypodiopsida) by caterpillars of Argyrosticta Hübner (Lepidoptera): a possible case of Mimicry? American Fern Journal, vol. 101, no. 4, pp. 317-318. http://dx.doi.org/10.1640/0002-8444-101.4.317.

PATRA, B., BERA, S. and HICKEY, R.J., 2008. Soral crypsis: protective mimicry of a coccid on an indian fern. Journal of Integrative Plant Biology, vol. 50, no. 6, pp. 653-658. http:// dx.doi.org/10.1111/j.1744-7909.2008.00664.x. PMid:18713405.

SANTOS, M.G., CARVALHO, C.E.M., KELECOM, A., RIBEIRO, M.L.R.C., FREITAS, C.V.C., COSTA, L.M. and FERNANDES, L.V.G., 2005. Cianogênese em esporófitos de pteridófitas avaliada pelo teste do ácido pícrico. Acta Botanica Brasílica, vol. 19, no. 4, pp. 783-788. http://dx.doi.org/10.1590/ S0102-33062005000400014. 